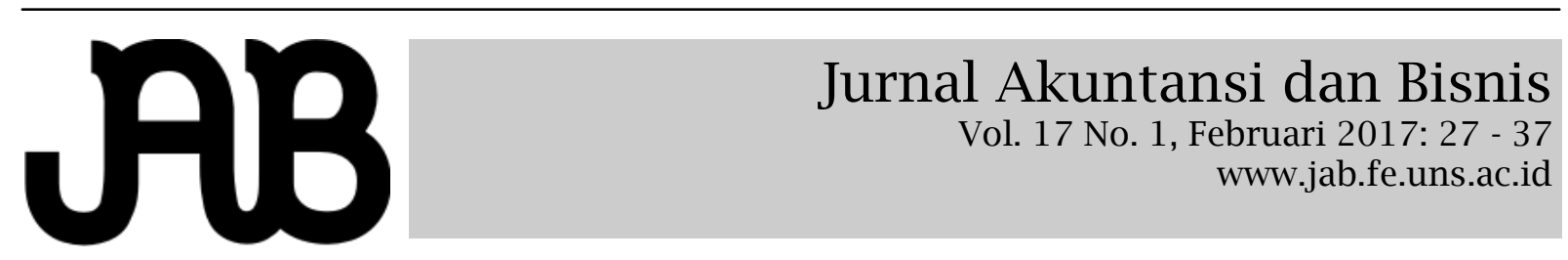

\title{
MERGER, AKUISISI, DAN KINERJA SAHAM PERUSAHAAN DI BURSA EFEK INDONESIA (BEI)
}

\author{
MOCHAMAD KHAIRUDIN \\ TRISNINIK RATIH WULANDARI (trisninik_rw@yahoo.com)
}

Program Studi Akuntansi, Fakultas Ekonomi dan Bisnis, Universitas Sebelas Maret

\begin{abstract}
A B S T R A C T
Mergers and acquisitions are important information for shareholders. An announcement of mergers or acquisitions issued by the company will affect the acquired company's share price or company's target. This study aims to examine the impact of corporate mergers and acquisitions. Their reaction depends on the initial announcement. The reaction of shareholders is used to measure abnormal return. The sample are 38 companies from different types of industries that conduct mergers and acquisitions over the 2011-2015 period. Paired Samples t-test is used to test whether there is an abnormal return after and before the merger and acquisition. The results of this study indicate that there is no difference abnormal return before and after the announcement of mergers and acquisitions.

Keywords : abnormal return, mergers and acquisitions

Merger dan akuisisi merupakan informasi penting bagi para pemegang saham. Pengumuman merger atau akuisisi yang dikeluarkan oleh suatu perusahaan akan mempengaruhi harga saham perusahaan yang diakuisisi atau perusahaan target. Penelitian ini mempunyai tujuan untuk menguji dampak yang timbul akibat merger dan akuisisi perusahaan. Reaksi mereka tergantung dari pengumuman awal. Reaksi para pemegang saham inilah yang digunakan untuk mengukur abnormal return. Perusahaan sampel yang di uji di sini adalah 38 perusahaan dari berbagai jenis industri yang berbeda-beda yang melakukan merger dan akuisisi selama periode 2011-2015. Paired Samples t-test digunakan untuk menguji ada tidaknya abnormal return setelah dan sebelum dilakukan merger dan akuisisi. Hasil penelitian ini menunjukan bahwa tidak ada perbedaan abnormal return sebelum dan sesudah pengumuman merger dan akuisisi..

Kata kunci : abnormal return, merger dan akuisisi
\end{abstract}

\section{PENDAHULUAN}

Perusahaan-perusahaan tidak hanya harus menghadapi krisis, tetapi juga harus menghadapi persaingan yang semakin ketat karena globalisasi, terutama masuknya produk-produk impor. Selain itu juga adanya perubahan-perubahan deregulasi, kemajuan teknologi dan telekomunikasi dan teknologi serta perubahanperubahan sektor lain yang juga mempengaruhi ekonomi. Respon yang dilakukan oleh perusahaan-perusahaan berbeda-beda untuk menghadapinya beragam. Ada yang memilih resources pada suatu segmen tertentu yang lebih kecil, ada juga yang bertahan dengan apa yang telah dilakukan selama ini, ada juga yang menggabungkan diri menjadi satu perus- ahaan besar dalam satu industri (merger atau akuisisi).

Menurut Ross, Westerfield, dan Jordan (2008), merger adalah penggabungan dua perusahaan atau lebih dimana perusahaan pengakuisisi mempertahankan nama dan identitasnya dan mengakuisisi semua aset dan liabilitas dari perusahaan yang diakuisisi. Sedangkan menurut PSAK 22, Akuisisi adalah suatu penggabungan usaha dimana salah satu perusahaan yaitu pengakuisisi memperoleh kendali atas aset neto dan operasi perusahaan yang diakuisisi.

Pengumuman merger dan akuisis adalah informasi yang sangat penting dalam suatu industri, karena dua perusahaan akan menyatukan kekuatannya. 
Konsekuensinya intensitas persaingan dalam satu industri akan berubah. Dengan demikian, pengumuman merger dan akuisisi sebagai suatu informasi dapat berpengaruh tidak hanya pada kedua perusahaan yang melakukan merger, yaitu perusahaan pengakuisisi (akuisitor) dan perusahaan yang diakuisisi, namun juga perusahaan lain yang menjadi pesaing yang berada dalam satu jenis industri yang sama dengan akuisitor dan yang diakuisisi.

Perusahaan perlu mengembangkan suatu strategi yang tepat agar dapat mempertahankan eksistensinya dan memperbaiki kinerjanya. Salah satu usaha untuk menjadi perusahaan yang besar dan kuat adalah melalui ekspansi. Ekspansi perusahaan dapat dilakukan baik dalam bentuk ekspansi internal maupun ekspansi eksternal. Ekspansi internal terjadi pada saat divisi-divisi yang ada dalam perusahaan tumbuh secara normal melalui kegiatan capital budgeting. Sedangkan ekspansi eksternal dapat dilakukan dalam bentuk penggabungan usaha.

Pada dasarnya tindakan merger dan akuisisi dilakukan oleh perusahaan untuk menuju ke arah yang lebih baik sehingga pasar diharapkan akan bereaksi terhadap peristiwa tersebut. Publikasi informasi merger dan akuisisi yang disampaikan oleh perusahan ke pasar dimaksudkan untuk memberi sinyal terhadap adanya peristiwa tertentu (publikasi akuisisi) yang dapat mempengaruhi nilai perusahaan. Reaksi pasar terhadap adanya peristiwa publikasi merger dan akuisisi dapat dilihat dari perubahan harga saham perusahaan akuisitor. Reaksi pasar modal terhadap kandungan informasi dalam suatu peristiwa dapat diukur dengan menggunakan $a b-$ normal return yang merupakan selisih antara actual return dengan expected return (Jogiyanto, 2015).

Beberapa penelitian yang sudah dilakukan sebelumnya menunjukan hasil yang beragam. Penelitian yang dilakukan oleh Wiriastuti (2010), Hanik (2011), Rusnanda (2013), Hidayat (2013) dan Khoirullah (2014) meneliti tentang analisis dampak pengumuman merger dan akuisisi terhadap abnormal return saham perus- ahaan akuisitor. Hasilnya adalah tidak ada perbedaan abnormal return sebelum dan sesudah pengumuman merger dan akuisisi.

Sedangkan Hutagalung (2002), Saiful (2003), Payamta dan Setiawan (2004) dalam penelitiannya mengindikasikan adanya perbedaan yang signifikan dari abnormal return sebelum dan sesudah merger dan akuisisi. Demikian juga dengan Astria (2012) dan Sundari (2016) membuktikan bahwa ada perbedaan signifikan abnormal return pada periode sebelum-sesudah pengumuman merger dan akuisisi. Berdasarkan hasil pengujian, dapat disimpulkan bahwa pengumuman merger dan akuisi merupakan kabar baik bagi pelaku pasar untuk berinvestasi di pasar modal sehingga tujuan dari merger dan akuisisi untuk menghasilkan sinergi dapat tercapai.

Dengan melihat hasil penelitian yang masih beragam, penelitian ini dilakukan dengan tujuan untuk memberikan bukti empiris tentang pengaruh pengumuman merger dan akuisisi terhadap kinerja saham pada perusahaan akuisitor sebelum dan sesudah merger dan akuisisi. Hasil bukti empiris tersebut diharapkan dapat memberikan manfaat bagi perusahaan akuisitor serta para pemegang saham dan pelaku bisnis lainnya dalam membuat keputusan ekonomi yang berkaitan dengan perubahan keuntungan yang disebabkan oleh merger dan akuisisi di Bursa Efek Indonesia (BEI).

\section{TIJAUAN PUSTAKA DAN PENGEM- BANGAN HIPOTESIS Signaling Theory}

Informasi merupakan unsur penting bagi investor dan pelaku bisnis karena informasi pada hakekatnya menyajikan keterangan, catatan atau gambaran baik untuk keadaan masa lalu, saat ini maupun keadaan masa yang akan datang bagi kelangsungan hidup suatu perusahaan. Informasi yang lengkap, relevan, akurat dan tepat waktu sangat diperlukan oleh investor di pasar modal sebagai alat analisis untuk mengambil keputusan investasi.

Menurut Jogiyanto (2015), informasi yang dipublikasikan sebagai suatu pengumuman akan memberikan signal bagi inves- 
tor dalam pengambilan keputusan investasi. Jika pengumuman tersebut mengandung nilai positif, maka diharapkan pasar akan bereaksi pada waktu pengumuman tersebut diterima oleh pasar. Reaksi pasar ditunjukkan dengan adanya perubahan volume perdagangan saham. Pada waktu informasi diumumkan dan semua pelaku pasar sudah menerima informasi tersebut, pelaku pasar terlebih dahulu menginterpretasikan dan menganalisis informasi tersebut sebagai signal baik (good news) atau signal buruk (bad news). Jika pengumuman informasi tersebut sebagai signal baik bagi investor, maka terjadi perubahan dalam volume perdagangan saham.

Teori sinyal atau signaling theory merupakan kebijakan yang diambil oleh emiten, pemerintah atau investor pada prinsipnya memberikan sinyal atau pertanda kepada pasar tentang kecenderungan atau tren di masa yang akan datang. Aktivitas merger dan akuisisi mempunyai nilai informatif bagi investor sehingga akan mempengaruhi keputusan investasi dalam bentuk perubahan harga saham karena adanya transaksi yang meningkat atau menurun.

Signaling theory juga menunjukkan adanya informasi asimetri antara manajemen perusahaan dengan pihakpihak lain yang dilakukan oleh manajemen. Informasi tersebut diharapkan menjadi kabar baik (good news) yang dapat direspon secara positif dalam bentuk investasi pada perusahaan, atau menjadi kabar buruk (bad news) sehingga tidak melakukan investasi (respon negatif).

\section{Merger}

Merger berasal dari bahasa latin "mergere" yang berarti bergabung bersama, menyatu, berkombinasi. Merger dapat diartikan pula hilangnya suatu identitas karena terserap atau tertelan sesuatu. Merger atau penggabungan kombinasi dari dua atau lebih perusahaan, dengan salah satu nama perusahaan yang bergabung tetap digunakan (Foster dalam Wibowo \& Pakereng, 2001) Dalam hal ini salah satu perusahaan akan tetap ada, sedangkan yang lainnya menjadi hilang. Merger bisa merupakan suatu langkah yang dilakukan mengikuti tinda- kan akuisisi 100 persen namun dalam akuisisi 100 persen, kedua belah pihak tetap ada yaitu baik itu perusahaan pengakuisisi (acquirer) maupun perusahaan target (Ang, 1997).

Merger adalah kombinasi dari dua atau lebih perusahaan, dengan salah satu nama perusahaan yang bergabung tetap digunakan sedangkan yang lain dihilangkan (Foster, 1986, dalam Hutagalung 2002). Dari ilustrasi diatas sebagai contoh perusahaan A akan merger dengan perusahaan $\mathrm{B}$, kemudian hanya ada satu perusahaan saja yang akan tetap beroperasi sedangkan yang satu lagi akan hilang, misal hanya perusahaan A atau B saja yang akan ada.

Sedangkan menurut Marcel (1992, dalam Hutagalung 2002), merger adalah suatu penggabungan perseroan, dimana sebuah perseroan mengambil alih satu atau lebih perseroan yang lain, Setelah terjadi pengambil-alihan tersebut, maka perseroan yang diambil-alih dibubarkan atau dilikuidasi. Sehingga eksistensinya sebagai badan hukum lenyap. Dengan demikian kegiatan usahanya dilanjutkan oleh perseroan yang mengambil alih.

\section{Akuisisi \\ Pengertian akuisisi berasal dari kata acquisition (bahasa latin) atau acquisi- tion (bahasa inggris), yang berarti membeli atau mendapatkan sesuatu atau obyek ter- tentu untuk kemudian ditambahakan pa- da sesuatu atau obyek tertentu yang telah dimiliki.}

Akuisisi merupakan salah satu bentuk pengambil-alihan (Husnan, 2002). Akuisisi dapat dibedakan menjadi akuisisi saham dan akuisisi asset. Akuisisi saham merupakan pengambil-alihan atau pembelian saham suatu perusahaan dengan menggunakan kas, saham atau sekuritas lain. Akuisisi saham biasanya melaui tahap penawaran (tender offer) oleh perusahaan penawar (bidder firm) kepada para pemegang saham perusahaan target. Akuisisi ini tidak membutuhkan persetujuan pihak manajemen. Akuisisi dapat dilakukan meskipun pihak manajemen tidak menyetujui pembelian saham perusahaan. Oleh karena itu akui- 
sisi ini disebut bentuk pengambil-alihan yang tidak besahabat (hostile takeover). Sedangkan akuisisi asset dilakukan dengan cara membekukan sebagian aset perusahaan target oleh perusahaan pengakuisisi. Akuisisi jenis ini membutuhkan suara pemegang saham perusahaan target untuk menyetujui pengambil-alihan perusahaan tersebut (Rachmawati \& Tandelilin, 2000).

\section{Abnormal Return}

Abnormal return umumnya menjadi fokus dalam studi yang mengamati reaksi harga atau efisiensi pasar. Abnormal return merupakan selisih antara return yang sesungguhnya terjadi dikurangi return yang diharapkan atau return ekspektasi (Jogiyanto, 2015). Dengan kata lain $A b-$ normal return merupakan kelebihan dari return yang sesungguhnya terhadap return normal.

Return normal merupakan return ekspektasi (return yang diharapkan investor). Return yang sesungguhnya merupakan return yang terjadi pada waktu ke-t yang merupakan selisih harga sekarang dengan harga sebelumnya. Sedangkan return yang diharapkan merupakan return yang harus di estimasi.

Abnormal return akan terjadi apabila pengumuman merger dan akuisisi mempunyai kandungan informasi dalam pasar modal yang efisien, harga saham dan tingkat pengembalian bereaksi dengan adanya pengumuman merger dan akuisisi sehingga dengan memanfaatkan informasi publik (public information), maka perusahaan dapat memperoleh keuntungan diatas normal. Brown dan Warner dalam Jogiyanto (2015) menjelaskan untuk mengestimasi return yang diharapkan digunakan tiga model, yaitu:

\section{Mean Adjusted Model}

Model disesuaikan rata-rata (Mean Adjusted Model) ini menganggap bahwa return ekspektasi bernilai konstan dan sama dengan rata-rata return realisasi sebelumnya selama periode estimasi return yang diharapkan dihitung dengan cara membagi return realisasi suatu perusahaan pada periode estimasi dengan lamanya periode estimasi.

Periode estimasi (estimation period) umumnya merupakan periode sebelum periode peristiwa. Periode peristiwa (event period) disebut juga periode pengamatan atau jendela peristiwa (event window).

\section{Market Model}

Dalam model pasar, return yang diharapkan dihitung melalui 2 tahap: pertama membentuk model ekspektasi dengan mengunakan data realisasi selama periode estimasi. Sebelumnya ditentukan dulu event period-nya. Model ekspektasi ini dapat dibentuk dengan menggunakan teknik regresi OLS (Ordinary Least Square) untuk memperoleh parameter $\alpha$ (alfa) dan $\beta$ (beta). Beta dihitung berdasarkan data historis dari sekuritas dan return pasar selama periode estimasi. Setelah model- model estimasi dari tiap sekuritas diperoleh selanjutnya adalah menghitung return estimasi untuk hari-hari periode jendela. Return ekspektasi untuk sekuritas $i$ pada hari ke-t dapat diestimasi dengan memasukan nilai return indeks pasar untuk hari ke-t ke dalam model ekspektasinya. Langkah selanjutnya adalah menghitung abnormal return. Abnormal return dihitung dari selisih antara return sesungguhnya pada periode jendela dengan return ekspektasi pada periode jendela yang telah didapat sebelumnya. Beta menunjukan kemiringan (slope) garis regresi. Alfa menunjukan intercept dengan sumbu Rit.

Perhitungan return ekspektasi dengan model pasar dilakukan dengan dua tahap, yaitu: membentuk model ekspektasi dengan menggunakan data realisasi selama periode estimasi dan menggunakan model ekspektasi ini untuk mengestimasi return ekspektasi di periode jendela. Model ekspektasi dapat dibentuk dengan menggunakan teknik regresi OLS (Ordinary Least Square) dengan persamaan 1.

$$
\mathrm{R}_{\mathrm{i}, \mathrm{j}}=\alpha_{1}+\beta_{1} \cdot \mathrm{R}_{\mathrm{mj}}+\varepsilon_{\mathrm{i} . \mathrm{j}}
$$

$\mathrm{R}_{\mathrm{i}, \mathrm{j}}$ adalah return realisasi sekuritas ke -i pada periode estimasi ke-j; $\alpha_{1}$ adalah intercept untuk sekuritas ke-I; $B_{1}$ adalah koefisien slope yang merupakan Beta dari sekuritas ke-I; $\mathrm{R}_{\mathrm{mj}}$ adalah return indeks pasar pada periode estimasi ke-j $\left(\mathrm{R}_{\mathrm{mj}}=\right.$ 
IHSGj - IHSG j-1 / IHSGj-1); $\varepsilon_{\mathrm{i}, \mathrm{j}}$ adalah kesalahan residu sekuritas ke-i pada periode estimasi ke-j.

\section{Market Adjusted Model}

Model disesuaikan pasar (market Adjusted model) menganggap bahwa penduga terbaik untuk mengestimasi return suatu sekuritas adalah return indeks pasar pada saat tersebut. Dengan menggunakan model ini tidak perlu menggunakan periode estimasi untuk membentuk model estimasi, karena return saham yang di estimasi adalah indeks pasar (Jogiyanto, 2015). Persamaan 2 digunakan untuk menghitung abnormal return.

$$
\mathrm{AR}_{\mathrm{it}}=\mathrm{R}_{\mathrm{it}}-\mathrm{R}_{\mathrm{mt}}
$$

$\mathrm{AR}_{\text {it }}$ adalah abnormal return dari masing-masing saham i pada hari k-t; $\mathrm{R}_{\text {it }}$ adalah actual retun saham i pada hari ke-t; $\mathrm{R}_{\mathrm{mt}}$ adalah return pasar pada hari ke-t

\section{Return Saham}

Return saham merupakan keuntungan atau hasil dari suatu investasi saham. Return saham dapat dibedakan menjadi dua yaitu return sesungguhnya (realized return) dan return yang diharapkan atau return ekspektasi (Expected Return).

Return sesungguhnya merupakan return yang sudah terjadi yang dihitung dari selisih harga sekarang relatif terhadap harga sebelumnya, Return dapat dihitung berdasarkan data historis. Return realisasi ini penting dalam mengukur kinerja perusahaan dan sebagai penentuan return dan resiko dimasa mendatang yang bersifat tidak pasti.

Komposisi perhitungan return saham terdiri dari capital gain (loss) dan deviden. Capital gain (loss) merupakan selisih laba atau rugi yang dialami oleh investor pemegang saham, karena harga saham relatif lebih tinggi atau lebih rendah dibandingkan dengan harga sebelumnya. Sedangkan deviden merupakan bagian dari laba perusahaan yang dibagikan pada periode tertentu sesuai dengan keputusan manajemen.

Bila prospek perusahaan membaik maka harga saham tersebut akan mening- kat. Dengan naiknya harga saham tersebut maka diharapkan return saham juga akan mengalami kenaikan karena return saham merupakan selisih harga antara harga saham sekarang dikurangi dengan harga saham sebelumnya (Husnan, 1998). Jika saham mengalami stock slit, maka harga pasar teoritis saham tersebut akan mengalami penyesuian, walaupun tidak terjadi dilusi, karena hak pemecahan saham (stock split) ini masih dimiliki oleh pemegang saham (Ang, 1997). Harga teoritis saham sebagai penyesuaian harga dapat dihitung dengan persamaan 3 .

$$
\mathrm{P}_{\mathrm{s}}=\mathrm{R}_{\mathrm{s}} \times \mathrm{P}_{\mathrm{x}}
$$

$\mathrm{P}_{\mathrm{s}}$ adalah harga pasar teoritis saham dengan nilai nomonal baru; $\mathrm{P}_{\mathrm{x}}$ adalah harga pasar saham; Rs adalah rasio stock split.

Beberapa pengukuran return realisasi yang banyak digunakan adalah return total, relatif return, kumulatif return, return realisasi individual dan return yang disesuaikan. Sedangkan rata-rata dari return dapat dihitung berdasarkan rata rata aritmatika atau rata-rata geometrik. $R e-$ turn saham yang digunakan dalam penelitian ini adalah return total. Besarnya return total dapat dihitung dengan persamaan 4.

Return Saham $=\frac{P-P_{t-1}}{P_{t-1}}$

$\mathrm{P}_{\mathrm{t}}$ adalah harga saham i pada periode t; Pt-1 adalah harga saham i pada periode t1.

Pemodal selalu menyukai informasi yang diharapkan memberikan tingkat keuntungan (return) yang sama, tetapi mempunyai resiko yang lebih kecil atau dengan resiko yang sama tetapi diharapkan memberikan tingkat keuntungan yang lebih besar. Investor bersedia melakukan investasi bila obyek investasi tersebut mampu menghasilkan keuntungan yang lebih besar dibandingkan obyek investasi lainnya kebanyakan investor mengharapkan diperolehnya hasil dari pembelian saham terhadap 2 hal yaitu Pertama, Kenaikan modal. Para investor mengharapkan kenaikan modal dalam bentuk kenaikan harga saham yang telah dibeli (capital gain. 
Kedua, Deviden. Para investor sampai tahun tertentu akan mengharapkan adanya pembagian laba yang diperoleh dalam bentuk deviden.

\section{Expected Return}

Dalam sesuaian pasar (market adjusted model) menganggap bahwa praduga yang terbaik untuk mengestimasi return suatu sekuritas adalah return indeks pasar pada saat tersebut. Dengan menggunakan market adjusted model maka tidak perlu munggunakan periode estimasi untuk membentuk model estimasi, karena return saham yang diestimasi adalah sama dengan return pasar.

\section{Indeks Harga Saham}

Hadi (2013), mengartikan "indeks harga saham adalah indikator yang menunjukan pergerakan harga saham." Indeks harga saham merupakan satu parameter yang dijadikan rujukan investor, analis, bahkan masyarakat awam sekalipun. Hingga saat ini PT Bursa Efek Indonesia sebagai suatu lembaga yang mengelola pasar modal di Indonesia telah memiliki 11 jenis indeks harga saham. Terdapat beberapa jenis indeks harga saham yang secara umum diketahui oleh publik, yaitu:

1. Indeks Harga Saham Gabungan (IHSG), yaitu jenis indeks harga saham yang menggunakan seluruh saham emiten yang terdaftar di BEI sebagai komponen perhitungan indeks.

2. Indeks LQ45, yaitu jenis indeks harga saham yang menggunakan 45 saham emiten yang terpilih sebagai sahamsaham paling likuid.

3. Jakarta Islamic Indeks (JII), yaitu jenis indeks harga saham yang menggunakan 30 saham emiten yang termasuk kedalam kriteria syariah.

\section{Pengembangan Hipotesis}

Strategi merger dan akusisi dipandang sebagai salah satu alternatif strategi yang dapat memacu pertumbuhan sebuah perusahaan atau kelompok usaha secara signifikan. Hitt (2002), menyatakan merger dan akuisisi dilakukan untuk menciptakan nilai bagi pemegang saham. Selain itu ada pendapat bahwa merger dan akuisisi sebaiknya hanya dilakukan jika pemegang saham pengakuisisi mendapat keuntungan. Dalam merger dan akusisi "nilai" tercipta jika manfaat sinergi diperoleh melalui penggabungan tersebut. Disamping itu jauh sebelum pengumuman efektif merger perusahaan pengakuisisi telah menginformasikan rancangan merger kepada pemegang saham. Reaksi pemegang saham akan tercermin pada harga saham perusahaan, jika investor menganggap pengumuman merger dan akuisisi merupakan sinyal positif, maka harga saham akan meningkat dan investor mendapatkan abnormal return yang positif diseputar pengumuman merger dan akuisisi.

Penelitian yang dilakukan oleh $\mathrm{Hu}$ tagalung (2002), mengenai reaksi pemegang saham terhadap pengumuman merger dan akuisisi di Bursa Efek Jakarta, yang mana hipotesisnya menyatakan bahwa adanya perbedaan rata- rata abnormal return positif yang diterima perusahaan. Hasil dari penelitian ini adalah ada perbedaan signifikan positif rata-rata abnormal return yang diterima perusahaan sebelum dan sesudah merger dan akuisisi.

Saiful (2003), melakukan penelitian terhadap pengumuman merger dan akuisisi terhadap abnormal return perusahaan target dan industri sejenis dari tahun 19911997, penelitian menggunakan teknik event study. Sampel akhir yang memenuhi kriteria adalah 30 perusahaan target dan 241 perusahaan non target dalam industri sejenis. Hasil dari penelitian ini telah ditemukan rata- rata dan kumulatif abnormal return yang diperoleh perusahaan target dan non target dalam industri sejenis adalah positif. Berdasarkan telaah literatur dan beberapa peneliti mengenai pengaruh pengumuman merger dan akuisisi terhadap abnormal return maka hipotesis yang diajukan adalah:

H1 : Abnormal return berbeda secara signifikan antara sebelum dan sesudah pengumuman merger $\&$ akuisisi.

METODE PENELITIAN

Definisi Operasional dan Pengukuran

Variabel

Variabel Independen

Sugiyono (2011) variabel independen meru- 
pakan variabel yang mempengaruhi atau yang menjadi sebab perubahannya atau timbulnya variabel dependen (terikat). Variabel independen dalam penelitian ini adalah peristiwa pengumuman Merger dan Akuisisi tiap perusahaan pada saat periode pengamatan.

\section{Variabel Dependen}

Sugiyono (2011) menjelaskan bahwa variabel dependen merupakan variabel yang dipengaruhi atau yang menjadi akibat, karena adanya variabel independen. Dalam penelitian ini adalah variabel komulatif abnormal return. Pengukuran abnormal return diukur dengan menggunakan proksi kinerja saham perusahaan.

1. Abnormal Return dihitung dengan Market Adjusted Abnormal Return, yaitu merupakan selisih return saham yang dihitung dari return individual dikurangi return ekspektasi.

$$
A R_{i t}=R_{i t}-E\left(R_{i t}\right)
$$

$\mathrm{AR}_{\text {it }}$ adalah abnormal return saham pada periode $\mathrm{t} ; \mathrm{R}_{\mathrm{it}}$ adalah return saham $\mathrm{i}$ pada periode $\mathrm{t}$; $\mathrm{E}\left(\mathrm{R}_{\mathrm{it}}\right)$ adalah return ekspektasi pada periode $t$.

2. Return saham individual pada periode t, merupakan selisih antara harga saham i ada periode $t$ dengan periode sebelumnya ( $t-1)$, dibagi dengan harga saham pada $\mathrm{t}-1$.

$$
R_{i t}=\frac{P_{i t}-P_{i t-1}}{P_{i t-1}}
$$

$\mathrm{P}_{\mathrm{it}}$ adalah harga saham i pada saat $\mathrm{t} ; \mathrm{P}_{\mathrm{jt}-1}$ adalah harga saham $\mathrm{j}$ pada saat $\mathrm{t}-1 ; \mathrm{R}_{\mathrm{jt}}$ adalah return saham i pada saat $\mathrm{t}$

3. Return Ekspektasi (expected return) merupakan selisih antara IHSG periode $t$ dengan $t-1$ dibagi dengan IHSG pada bulan $\mathrm{t}-1$.

$$
E\left(R_{i t}\right)=\frac{I_{m t}-I_{m t-1}}{I_{m t-1}}
$$

$E\left(R_{i t}\right)$ adalah return ekspektasi pada saat $\mathrm{t}$; I $\mathrm{mt}_{\mathrm{t}}$ adalah IHSG pada saat $\mathrm{t}$; $\mathrm{I}_{\mathrm{mt-1}}$ adalah IHSG pada saat t-1

\section{Populasi dan Sampel}

Populasi yang digunakan dalam penelitian ini adalah seluruh perusahaan yang terdaftar di BEI dengan periode penelitian selama 5 tahun yaitu dari tahun 2011-2015 yaitu sejumlah 557 perusahaan.

\section{Sampel}

Penentuan kriteria sampel diperlukan untuk menghindari timbulnya mispesifikasi dalam penentuan sampel penelitian yang selanjutnya akan berpengaruh terhadap hasil penelitian. Adapun sampel penelitian ini adalah seluruh perusahaan yang menjadi populasi dan telah melakukan merger dan akuisisi. Pengambilan sampel menggunakan metode purposive sampling yaitu pengambilan sampel dengan membuat batasan tertentu agar sesuai dengan kriteria yang digunakan dalam penelitian ini. Adapun kriteria tersebut antara lain sebagai berikut:

1. Perusahaan yang terdaftar di Bursa Efek Indonesia (BEI) pada periode tahun 2011 sampai dengan tahun 2015 dan dalam berbagai sektor industri.

2. Perusahaan yang melakukan aktivitas merger atau akuisisi dalam masa periode 2011-2015

3. Tanggal pengumuman merger dan akuisisi tidak diikuti oleh kejadian lain yang dapat mempengaruhi abnormal return saham, seperti pembagian deviden, stock split, dan kegiatan lainnya yang mempengaruhi peristiwa merger dan akuisisi selama periode pengamatan.

Berdasarkan sampel penelitian, namun yang memenuhi persyaratan untuk menjadi sampel akhir dalam penelitian hanya 38 perusahaan.

\section{Jenis dan Sumber Data}

Sumber data yang digunakan dalam penelitian ini adalah sumber data sekunder, yaitu sumber data penelitian yang diperoleh peneliti secara tidak langsung melalui media perantara (diperoleh dan dicatat oleh pihak lain) (Indriantoro dan Supomo, 2014). Sedangkan jenis data yang digunakan adalah data kuantitatif, yaitu data yang berupa simbol angka atau bilangan yang informasinya dapat dianalisis secara langsung menggunakan alat ukur atau uji statistik. Sehingga, data yang digunakan 
dalam penelitian ini adalah data yang diambil dari IDX (Indonesian Stock Exchange) melalui website www.idx.co.id dan www.financeyahoo.com, yaitu berupa data harga saham emiten yang dijadikan sampel penelitian pada periode pengama$\tan$.

Metode pengumpulan data yang digunakan dalam penelitian ini adalah metode dokumentasi, yaitu metode pengumpulan data yang dilakukan dengan cara melihat, meneliti, dan mencatat dokumen-dokumen yang memiliki kaitan dengan objek permasalahan dalam penelitian ini. Data yang dikumpulkan ini merupakan harga saham dari perusahaan yang mengumumkan informasi merger dan akuisisi rentang tahun 2011-2015.

\section{Metode Analisis Data}

Prosedur analisis data yang digunakan dalam penelitian ini adalah sebagai berikut:

1. Mengidentifikasi tanggal pelaksanaan akuisisi. Tanggal publikasi merger dan akuisisi (event date) yang dimaksud adalah tanggal pencatatan BEI ketika saham sudah dapat diperdagangkan, untuk mempermudah tanggal pencatatan maka diidentifikasi sebagai hari ke0 .

2. Menentukan jendela peristiwa (event window) atau periode dimana reaksi likuiditas perusahaan akibat pengumuman akuisisi. Event window yang digunakan adalah 10 hari sebelum dan 10 hari sesudah akuisisi. Penentuan event window tersebut menghindari pengaruh informasi lain yang dapat mempengaruhi perubahan harga saham emiten yang bersangkutan, jika periode peristiwa diambil terlalu lama, dikhawatirkan adanya peristiwa lain yang cukup signifikan mempengaruhi hasilnya.

3. Membuat perbandingan secara statistik rata-rata saham dengan menggunakan ukuran abnormal return dengan hari sebelum atau sesudah pelaksanaan merger dan akuisisi untuk melihat apakah terdapat perbedaan signifikan diantara kedua periode tersebut.

\section{Uji Hipotesis}

Metode yang digunakan untuk melakukan uji hipotesis dalam penelitian ini adalah dengan menggunakan paired samples ttest. Paired sample t-test atau uji t sampel berpasangan merupakan uji parametrik yang digunakan untuk menguji hipotesis sama atau berbeda diantara dua variabel. Mantravadi dan Reddy (2008) mengatakan rata-rata sebelum dan sesudah merger dan akuisisi serta dampak dari jenis-jenis merger terhadap kinerja keuangan dibandingkan dan diuji perbedaannya dengan menggunakan uji $\mathrm{t}$ untuk dua sampel. Paired two-sample t-test dianggap sesuai untuk mengukur merger yang menyebabkan kinerja perusahaan berubah. Dalam melakukan analisis ini digunakan sebuah alat bantu, yaitu dengan program komputer SPSS 23.0 For Windows Evaluation Version.

\section{ANALISIS DAN PEMBAHASAN Statistik Deskriptif}

Dari tabel 1 menunjukan bahwa pada saat sebelum merger dan akuisisi rata-rata $a b-$ normal return saham sebesar $-0,0083$ dengan standar deviasi sebesar 0,4809. Abnormal return saham terendah sebelum merger dan akuisisi sebesar $-0,118$ yang merupakan abnormal return. Sedangkan abnormal return saham tertinggi sebelum merger dan akuisisi sebesar 0,115 adalah Salim Ivomas Pratama Tbk.

Rata rata abnormal return saham sesudah merger dan akuisisi sebesar 0,0051 dengan standar deviasi sebesar 0,0485. Abnormal return saham terendah sesudah merger dan akuisisi sebesar 0,1306 yang merupakan Abnormal return dari PT Nusa Raya Cipta Tbk. Sedangkan

Tabel 1.

Statistik Deskriptif Pengujian Komulatif Abnormal Return

\begin{tabular}{lccccc}
\hline & $\mathrm{N}$ & Min. & Max. & Mean & $\begin{array}{l}\text { Std. } \\
\text { Dev }\end{array}$ \\
\hline $\begin{array}{l}\text { AR1 sebe- } \\
\text { lum }\end{array}$ & 38 &,- 1188 &, 1157 &,- 008342 &, 0480 \\
$\begin{array}{l}\text { AR2 } \\
\text { sesudah }\end{array}$ & 38 &,- 1306 & $, 1018,005113$ &, 0486 \\
$\begin{array}{l}\text { Valid N } \\
\text { (listwise) }\end{array}$ & 38 & & & & \\
\hline
\end{tabular}


abnormal return saham tertinggi sesudah merger dan akuisisi sebesar 0,1018 adalah Abnormal return PT Astra Internasional Tbk.

\section{Uji Hipotesis}

Hipotesis dalam penelitian ini adalah terdapat perbedaan komulatif abnormal return sebelum dan sesudah pengumuman merger dan akuisisi. Pengujian terhadap hipotesis dilakukan dengan menggunakan uji beda dua sampel berpasangan (paired sample t-test) yaitu untuk menguji populasi atau variabel berpasangan dan untuk melihat apakah terdapat perbedaan yang signifikan antara variabel yang dianggap memiliki hubungan.

Berdasarkan hasil uji $t$ dapat diperoleh nilai t-hitung $=-1,132$, dengan Sig. (2-tailed) $=0,265$. karena Sig. (2-tailed) $0,265>0,05$. Dengan demikian Hipotesis ditolak. Artinya tidak terdapat perbedaan komulatif abnormal return saham perusahaan akuisitor sebelum dan sesudah pengumuman merger dan akuisisi. Bedasarkan pengelolaan data tersebut, maka dapat disimpulkan bahwa hasil pengumuman merger dan akuisisi terhadap komulatif abnormal return saham perusahaan akuisitor tidak memiliki perbedaan yang signifikan.

\section{Pembahasan}

Hasil penelitian ini menunjukkan bahwa tidak ada perbedaan komulatif abnormal return saham sebelum dan sesudah pengumuman mrger dan akuisisi, dibuktikan dengan nilai sig. (2-tailed) sebesar 0,265 lebih besar daripada 0,05 yang artinya hipotesis ditolak. Berarti tidak ada perbedaan abnormal return saham perusahaan akuisitor sebelum dan sesudah peristiwa pengumuman merger dan akuisisi.

Hasil penelitian ini sesuai dengan hasil penelitian Hanik (2011), Hidayat (2013), dan Khoirullah (2014) yang menyatakan bahwa tidak ada perbedaan yang signifikan antara sebelum dan sesudah peristiwa merger dan akusisi. Dalam penelitian ini mengindikasikan bahwa tidak adanya pengaruh yang signifikan dari hasil pengujian ini adalah karena faktor pengumuman merger dan akuisisi yang dilakukan oleh emiten bukanlah merupakan sebuah kabar yang mengejutkan karena pada umumnya sebelum informasi mengenai hal tersebut pada umumnya sudah keluar ke publik atau adanya kebocoran infromasi terlebih dahulu sebelum dilakukan pengumuman, karena umumnya sudah dimasukkan dalam agenda rapat umum pemegang saham (RUPS). Hal ini juga membuktikan bahwa peristiwa merger dan akuisisi yang terjadi tidak menarik minat pasar, sehingga investor tidak tertarik menanamkan modalnya di perusahaan.

\section{SIMPULAN}

Penelitian ini dilakukan untuk menguji dampak pengumuman merger dan akuisisi terhadap komulatif abnormal return saham pada perusahaan akuisitor. Dari pengamatan 10 hari sebelum dan 10 hari sesudah pengumuman merger dan akuisisi tidak diperoleh adanya perbedaan yang signifikan. Uji hipotesis dengan Paired samples $t$ -test menunjukan tidak ada perbedaan yang signifikan 10 hari sebelum dan 10 hari sesudah pengumuman merger dan akuisisi dibuktikan dengan nilai pengujian menggunakan uji Paired Samples t-test dengan sig. (2-tailed) sebesar 0,265 lebih besar daripada 0,05 yang artinya hipotesis ditolak. Dari penelitian diatas dapat di tarik kesimpulan bahwa strategi merger dan akuisisi yang diterapkan oleh perusahaan tidak berpengaruh besar terhadap perusahaan.

Implikasi Penelitian ini bagi investor adalah dengan adanya merger dan akuisisi diharapkan dapat memperbaiki kinerja perusahaan sekaligus dapat menarik investor agar tertarik menanamkan modalnya pada pasar modal.

\section{KETERBATASAN DAN SARAN \\ Keterbatasan}

Penelitian ini memiliki keterbatasan pada beberapa hal, yaitu Pertama, penelitian ini hanya menggunakan periode 10 hari sebelum dan 10 hari sesudah pengumuman merger dengan menggunakan metode market adjusted model dalam pengukuran abnormal return saham sehingga memerlukan justifikasi model lain. Selain itu ada beberapa saham yang kurang aktif di- 
perdagangkan di Bursa Efek Indonesia. Kedua Penelitian ini hanya memasukan pengaruh pengumuman merger dan akuisisi tanpa mempertimbangkan variabelvariabel lain yang mungkin mempengaruhi abnormal return suatu perusahaan, misalnya nilai akuisisi, ukuran perusahaan target, alat pembayaran yang digunakan dalam merger dan akuisisi. Ketiga, Adanya saham yang memiliki return nol, berarti terdapat beberapa saham yang kurang aktif diperdagangkan. Keempat, adanya kebocoran informasi atau informasi yang telah terdistorsi mengenai pengumuman merger dan akuisis sehingga hal tersebut tidak menjadikan kabar yang mengejutkan sehingga dampak yang dirasakan tidak terlalu besar.

\section{Saran}

Saran untuk penelitian selanjutnya adalah sebagai berikut, pertama diperlukan analisis dengan memasukkan periode yang lebih panjang untuk sebelum dan sesudah merger sehingga sampel akan semakin besar. Kedua, sebaiknya penentuan sampel perusahaan dicari untuk kategori saham yang lebih aktif di BEI agar tidak menghasilkan return nol. Ketiga, perlunya kehati-hatian dalam melakukan merger dan akuisisi agar nantinya dapat memberi manfaat terhadap perusahaan dan para pemegang saham.

\section{DAFTAR PUSTAKA}

Ang, R. 1997.Buku pintar pasar modal Indonesia, (Edisi Pertama). Mediasoft Indonesia.

Astria, Nike. (2012). Analisis dampak pengumuman merger dan akuisisi terhadap abnormal return saham peusahaan akuisitor yang terdaftar di BEI tahun 2006 - 2008. (Skripsi). Universitas Brawijaya, Fakultas Ekonomi, Malang.

Hadi, Nor. (2013). Pasar modal acuan teoitis dan praktis investasi di instumen keuangan pasar modal. Yogyakarta: Graha Ilmu.

Hanik, U. (2011). Analisis dampak pengumuman merger dan akuisisi terhadap abnormal return saham perusahaan akuisitor study pada perusahaan akuisitor yang terdaftar di BEI tahun 2008 - 2011 (Skripsi). Universitas Islam Malang, Fakultas Ekonomi, Ma- lang.

Hitt, M.A. (2002). Merger dan Akuisisi: Panduan Bagi Para Pemegang Saham Untuk Meaih Laba, Terjemahan, (Cetakan Pertama), Jakarta : Erlangga.

Husnan, S. (1998). Dasar-dasar teori portofolio dan analisis sekuritas, (Edisi Kedua). Yogyakarta : UUP-AMP YKPN (2002). Manajemen keuangan teori dan penerapan: Keputusan jangka panjang (Edisi Keempat). Yogyakarta : BPFE UGM.

Hutagalung, A. (2002). Reaksi pemegang saham terhadap pengumuman merger dan akuisisi di bursa efek jakarta, Sinergi, 4(2).

Hidayat, R. (2013). Analisis dampak sebelum, sesudah pengumuman merger dan akuisisi terhadap abnormal return dan volume perdagangan saham pada perusahaan yang terdaftar di BEI. Jurnal Universitas Maritim Raja Ali Haji Tanjungpinang.

Indriantoro, N., \& Supomo B. (2014). Metodologi penelitian bisnis untuk akuntansi \& manajemen (Edisi 1). Yogyakarya : BPFE.

Jogiyanto, H. (2015). Teori portofolio dan analisis investasi (Edisi Kesepuluh).Yogyakarta: BPFE.

Khiorullah, A.L. (2014). Analisis dampak pengumuman akuisisi terhadap return saham perusahaan akuisitor dan yang diakuisisi (Skripsi). Universitas Jember, Fakultas Ekonomi, Jember.

Mantravadi, P., \& Reddy, A.V. (2008). Type of merger and impact on operating performance: indian experience. Economic and Political Weekly,43(39), 6674.

Payamta \& Setiawan, D. (2004). Analisis pengaruh merger dan akuisis terhadap kinerja perusahaan publik di Indonesia. Riset Akuntansi Indonesia, 7(3), 265-282.

Racmawati E \& Tendelilin E. (2001). Pengaruh pengumuman merger dan akuisisi terhadap return saham perusahaan target di bursa efek jakarta, Jurnal Riset Akuntansi, Manajemen dan Ekonomi, 16(2), 153-170.

Ross, S.A., Westerfield, R.W., \& Jordan, B.D. (2008). Corporate finance fundamentals: international student edition. New York: McGrow-Hill

Rusnanda, E, W. (2013). Analisa pengaruh pengumuman merger dan akuisisi terhadap abnormal return saham bank bank umum di bursa efek indonesia. GRADUASI, 29 Edisi Maret 2013. 
Saiful. (2003). Abnormal return perusahaan target dan industri sejenis sekitar pengumuman merger dan akuisisi. Jurnal riset ekonomi dan manjemen, 3(2).

Sugiyono. (2009). Metode penelitian bisnis (pendekatan kuantitatif, kualitatif, dan $R \& D)$. Bandung: Alfabeta.

Sundari, R.I. (2016). Kinerja merger dan akuisisi pada perusahaan Go Public. Telaah Bisnis. 17(1).

Wibowo, A \& Pakereng. Y. (2001). Pengaruh pengumuman merger dan akuisisi terhadap return saham perusahaan akuisitor dan non akuisitor dalam sektor industri yang sama di bursa efek jakarta, Jurnal Ekonomi dan Bisnis Indonesia 6(4), 372-387.

Wiriastari, Rahadiani. (2010). Analisis dampak pengumuman merger dan akuisisi terhadap return saham perusahaan akuisitor yang terdaftar di BEI tahun 2004-2008. (Skripsi). Universitas Diponegoro, Fakultas Ekonomi dan Bisnis, Semarang. 